\title{
Biological Effects of Selenium Compounds With a Particular Attention to the Ontogenetic Development
}

\author{
I. OŠŤÁDALOVÁ ${ }^{1,2}$
}

${ }^{1}$ Centre for Cardiovascular Research, Prague, Czech Republic, ${ }^{2}$ Institute of Physiology, Academy of Sciences of the Czech Republic, Prague, Czech Republic

Received January 23, 2012

Accepted May 3, 2012

\section{Summary}

Selenium is a trace element that is essential for living organism. Its beneficial effect is, however, expressed in a very narrow dosage range: the high and low doses of selenium are connected with pathological manifestations. The toxicity depends on the chemical form of selenium, state of organism, interactions with heavy metals and on the stage of ontogenetic development. Whereas one dose of sodium selenite $(20 \mu \mathrm{mol} / \mathrm{kg} \mathrm{b.w.})$ is lethal in adult rats, suckling rats are entirely resistant. However, within one week after administration of the same dose, cataract of eye lens developed. The highest incidence of cataract was observed in 10-day-old animals and it decreased until day 20. From postnatal day 20 to day 40 the rats were resistant to both the lethal and cataractogenic effects of selenium. The incidence of cataract may be suppressed by premature weaning, lower hydration of suckling, change of water soluble/water insoluble lens protein ratio, thyroxine treatment, and by interaction with mercury. By means of its oxidative and reduction properties, selenium is involved in the maintenance of the cell redox homeostasis. Typical example is its possible cardioprotective effect: selenium decreased number of arrhythmias, reduced infarct size and improved the contractile recovery after ischemia/reperfusion injury. Selenium supplementation may thus increase cardiac tolerance to ischemic damage.

\section{Key words}

Development • Selenium toxicity • Cataractogenic effect • Lethal effect $\bullet$ Cardioprotective effect

\section{Corresponding author}

I. Oštádalová, Institute of Physiology, Academy of Sciences of the Czech Republic, Vídeňská 1083, 14220 Prague 4, Czech Republic. E-mail: iostadal@biomed.cas.cz

\section{Introduction}

Selenium is a trace element that is essential for living organisms. The only source of selenium for mammalian food chain is the soil. The amount of selenium in the soil is not equal; it depends on the nature of soil and in particular on its $\mathrm{pH}$. There are geographic areas with high content of selenium e.g. in China, USA and Canada. On the other hand, there are areas with very low content of selenium as other areas in China, Finland and New Zealand (Robinson and Thompson 1981, Diplock 1993). Water washes the selenium out of soil so that plants take in selenium not only from soil but also from water. The concentration in plants is not identical, some plants are known as selenium accumulators since they are able to accumulate selenium against a concentration gradient. At the end of the food chain are people taking up selenium from a plant food directly, through animal food, and from water. In the organism, selenium is transported to the organs and cells; it passes well over placental barrier as well as through mother milk to sucklings (Allen and Miller 1981, Enjalbert et al. 1999). After ingestion by humans and animals, selenium is partly expired and mostly returned to the soil through urine and feces. Some relatively inert chemical forms of selenium are converted to selenite and selenate by soil bacteria.

\section{Selenium compounds}

Inorganic selenium forms, selenite and selenate, predominate in soil and water, whereas organic selenium 
compounds, selenomethionine and selenocysteine, predominate in plants and carnal food and milk. In contrast to thiols, selenols are largely ionized at neutral $\mathrm{pH}$ and they are anionic in the enzymes. The lower redox potential of selenol as compared with corresponding thiol may explain the presence of selenols in redox catalysts (Stadtman 1980). The discovery of selenium as an essential trace element of considerable physiological significance in warm-blooded animals comes from Schwarz and Foltz (1957). Rotruck and coworkers (1972) discovered that selenium is located in the active site of glutathione peroxidase, the enzyme which protects liver cells against mitochondrial swelling, and they described the exact structure of this enzyme.

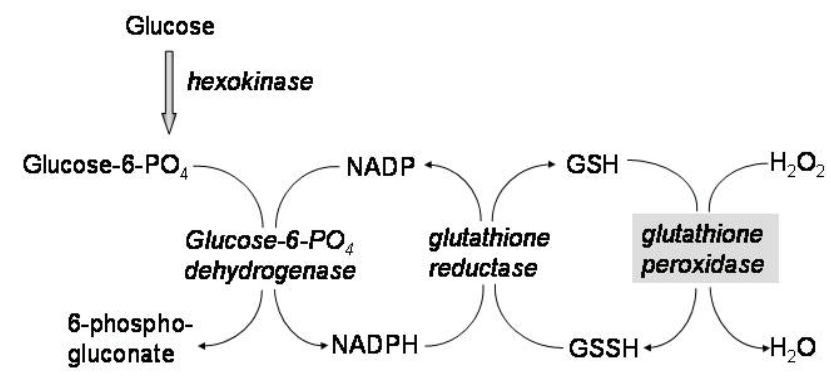

Fig. 1. Decomposition of ROS.

Selenium is a component of several enzymes. Cellular glutathione peroxidase (GPx) - the first identified selenium-dependent enzyme - converts reduced glutathione (GSH) to oxidized glutathione (GSSG) and simultaneously decomposes hydrogen peroxide. The reduction of hydrogen peroxide is coupled with the reduction of NADPH and conversion of glucose6-phosphate to 6-phosphogluconate. Glucose is necessary for preservation of GPx activity (Fig. 1). Tripeptide GSH, synthesized in most if not all mammalian cells, is a critical source of reducing power and is involved in a number of different functions (detoxication, disulfide bond formation, maintenance of thiol status, antioxidant defense, and modulation of proliferation, differentiation and apoptosis). The central cysteine group is essential in the regulation of sulfide bonds and in the disposal of oxidants. The antioxidant function is mediated by the redox active thiol group, which becomes oxidized when GSH simultaneously reduces target molecules. GSH (at millimolar concentrations in cells), can influence the redox potential, and can interfere with redox signalling. Later, other glutathione peroxidases were discovered: phospholipid hydroperoxide glutathione peroxidase
(GPX4, Ursini et al. 1985), extracellular glutathione peroxidase (GPX3, Takahashi and Cohen 1986), and gastrointestinal glutathione peroxidase (GPX2, Chu et al. 1993). At present, eight isozymes are known; they are encoded by different genes and vary in substrate specificity and cellular localization.

Iodothyronine deiodinases (Berry et al. 1991, Bianco et al. 2002) represent a new family of eukaryotic selenoproteins. They are localized in strategically important locations in the cells enabling them to act as gate-keepers to the nuclear receptors (Köhrle 1996). Three iodothyronine deiodinases were described: type I and II activate the thyroid hormone by converting $\mathrm{T}_{4}$ (thyroxine) to $\mathrm{T}_{3}$ (triiodothyronine), type III inactivates $\mathrm{T}_{3}$; the thyroid gland is thus rich in selenium. The experiments showed that the low levels of serum selenium or selenoprotein $\mathrm{P}$ do not necessarily interfere with regular functioning of the thyroid hormones axis. It seems that the 5'-deiodinase isoenzymes are preferentially supplied with selenium and that they are even less dependent on serum or brain selenium levels. Thyroid gland has a top priority in respect to the hierarchy of selenium supply in the organism (Schomburg et al. 2005). Expression of these selenoenzymes plays a role during embryonic development and in the regulation of metabolic rate.

Thioredoxin reductase is a ubiquitous protein with redox active cysteine residues. The reduced thioredoxin acts as an electron donor and also scavenges intracellular $\mathrm{H}_{2} \mathrm{O}_{2}$ while it is catalyzed by a family of thioredoxin-dependent peroxidases (it reduces thioredoxin and thereby regulates cellular protein thiol redox status) (Park and Suzuki 2007). Other biologically active selenium compounds are mitochondrial capsulae selenoprotein in the mouse spermia (Karimpour et al. 1992), selenoprotein W in skeletal muscles (Vendeland et al. 1995), and selenoprotein P (Yang et al. 1987) used as a biomarker of selenium status (Burk et al. 2003).

Considering the importance of selenium for different essential functions, a marker of selenium status would be very useful. However, there are different opinions. Blood platelets were considered in this respect because they have a relatively short biological life span and they seem to be useful for determination of actual selenium status (Levander et al. 1983). The other possibility is represented by erythrocytes, since they are at greater risk from peroxides than most other cells, due to their much higher concentration of oxygen (Chambers et al. 1986); they contain glutathione peroxidase which is 
a good indicator of long-term selenium intake. However, Xia et al. (2005) suggested that selenoprotein $P$ requires a greater selenium intake than full expression of plasma gluthatione peroxidase; selenoprotein $\mathrm{P}$ was thus recommended as a better indicator of selenium nutritional status than gluthatione peroxidase.

\section{Biological effect of selenium}

Selenium is an essential trace element and its beneficial effect is expressed in a very narrow dosage range. The high and low doses of selenium are connected with pathological manifestations (Fig. 2). However the availability and biological effects of selenium are dependent on a number of circumstances.

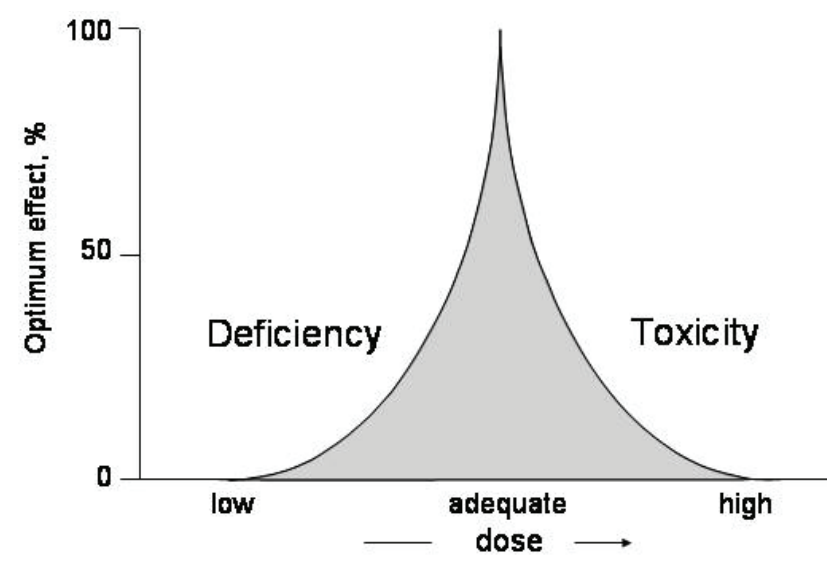

Fig. 2. Dose-dependent biological effects of selenium.

Dose

The effects of selenium are dose-dependent (Fig. 2). Recommended dietary allowance of selenium for healthy adults is $55 \mu \mathrm{g} /$ day (Schelenz 1987, Burk 2002); the dose for children, pregnant and lactating women has, however, not yet been determined.

Excessive dose of selenium induces toxicity both in humans and in animals. Acute human intoxication is rare and it is almost invariably fatal, manifested by stupor, hypotension and respiratory depression. Chronic selenium poisoning, reported in some areas in China, produces selenosis in humans and induces changes in the liver, skin, hairs and nails. Garlic odor of the breath is the evidence for expiration of dimethyl selenide and is an indicator of selenium intoxication (Barceloux 1999). Selenite biotransformation to dimethyl selenide involves a six valence reduction to $\mathrm{H}_{2} \mathrm{Se}$ and subsequent methylation. Both steps are exhausting and induce depletion of methyl groups and antioxidative reserves.

Toxic syndrome in different farm species of animals is more frequent. The first reasonable data came from Nebraska (Moxon 1938): the disorder was characterized by loss of hair and soreness of the feet and was named ,alkali disease“, since the farmers believed that it was caused by the alkali (high salt) waters and seepages of the area. Conclusive evidence that a high dose of selenium was responsible for this disease arose from the experiments of Franke and Potter (1936). Alkali disease was considered as a chronic stage of selenium intoxication, a state associated with the dizziness and designated as ,blind stagger"; it represents an acute form of intoxication.

Toxicity of selenium in rats is dependent on their selenium state. It was demonstrated that pretreatment with a low dose of selenium protects the rats against a lethal effect of other selenium compounds (Pařízek 1976, Kalousková and Pavlík 1982).

However, even selenium deficiency is connected with pathological states in animals: liver necrosis in vitamin E-deficient rats, exudative diathesis in chicken and ,white muscle disease“ in lambs and calves (Schwarz 1976). Moreover, selenium deficiency markedly enhances lipid peroxidation in the heart cells via depressed glutathione peroxidase activity that might be responsible for the decrease of $\mathrm{Ca}^{2+}$-ATPase and $\mathrm{Ca}^{2+}$ uptake activities in the sarcoplasmic reticulum in seleniumdeficient animals (Schwarz 1976, Wang et al. 1993).

In humans, selenium deficiency has been implicated as a pathogenic factor in the development of Keshan disease. It is a potentially fatal form of dilated cardiomyopathy restricted to the endemic areas in China (northeastern Chinese county Keshan) and seen in residents having an extremely low selenium status, with a prevalence in children (Yang 1985). Selenium deficiency is probably a necessary but not sufficient factor for the development of this cardiomyopathy. To trigger the disease, the infection by coxsakie B virus is essential. The administration of selenite inhibited the replication of coxsakie $\mathrm{B}$ virus and demonstrated the prophylaxis of Keshan disease (Cermelli et al. 2002). Pathological, biochemical as well as clinical studies of Keshan disease demonstrated an increase of enlarged and swollen cardiac mitochondria with distended crista membranes, together with a significant reduction in the activity of oxidative phosphorylation. It was, therefore, suggested that mitochondria are the predominant target of the pathogenic factors of the disease. On the basis of these 
results it was considered that Keshan disease might be classified as ,mitochondrial cardiomyopathy“ endemic in China (Fuyu 2006). Selenium deficiency and antioxidant status in general increase the sensitivity to viral infections. Severe pathology of hearts was demonstrated in mice infected with a myocarditic coxsakie virus B3 (CVB3/20) (Beck et al. 1994). Another syndrome of selenium deficiency in humans is the Kashin-Beck illness. This disease is induced by the selenium deficiency, together with the iodine deficiency, and results in atrophy, degeneration and necrosis of cartilage tissue (Moreno-Reyes et al. 1998).

In this connection, it is necessary to mention that selenium pathology is a subject of a new scientific discipline - geomedicine - dealing with the influence of natural factors on the geographical distribution of problems in human and veterinary medicine (Steinnes 2009).

\section{Chemical form}

For the biological effects of selenium its chemical form is also very important. Selenium is usually determined as its total concentration. However, different chemical forms of selenium have different toxic potentials and effects. Organic compounds of selenium are more effective in comparison with inorganic compounds. Selenium as selenomethionine has nearly twice the bioavailability of selenium as selenite (Xia et al. 2005). The different bioavailability of selenium compounds contributes to the controversy of selenium action.

\section{State of the organism}

Another important factor for biological effect of selenium is the state of the organism, the inherited characteristics, previous history, physiological state, gender, nutritional status, the supply of other trace elements, and concomitant effects of other simultaneously acting factors of the environment (Pařizek 1975, Pařízek et al. 1980). Selenium enters into interactions with nutritional status of the animals and humans. For example, the compensated selenium deficiency can become decompensated by simultaneous vitamin $\mathrm{E}$ or $\mathrm{C}$ deficiency or by prooxidative nutrients (Mertz 1985, Duarte and Lunec 2005). It is interesting to mention that the prooxidant vs. antioxidant properties of vitamin $\mathrm{C}$ are in its concentration, since in vitro data suggest that at low levels of vitamin $\mathrm{C}$ it can act as a prooxidant, but as an antioxidant at high levels. However, in vivo evidence for this contention is lacking, and there are data showing that vitamin $\mathrm{C}$ predominantly reduces in vivo oxidative damage (Buettner and Jurkiewicz 1996).

\section{Interactions with other elements}

Selenium enters into the interactions with a number of other elements. Selenite acts as a strong oxidative agent with a powerful lethal action (Oštádalová et al. 1978). We have shown (Pařízek and Oštádalová 1967) that administration of selenite prevents completely the toxic effect of sublimate, and on the contrary, a single dose of sublimate stopped lethal effect of selenite. The protective effect is, however, not connected with the increased excretion, but with increased retention of both mercury and selenium in the organism, and with a decrease of excretion of both elements (Pařízek et al. 1971a). Similar treatment of pregnant rats decreases the transfer of these elements into fetuses and analogous treatment of lactating rat females decreases the content of these elements in the milk and their transfer to sucklings (Pařízek et al. 1969a, 1969b, 1971a, 1971b). It might be supposed that selenium and heavy metals, e.g. mercury, form a complex or that they may compete for binding sites of proteins or other compounds. Mercury increases the content of selenium in the organism, however, in the nonavailable form, and in this way decreases both the disposal of biological effective selenium at low doses (Gasiewicz and Smith 1978, Skerfving 1978, Agarwal and Behari 2007, Su et al. 2008), and toxicity of high doses of selenium compounds. Similar interactions were also observed between selenium and cadmium (Pařízek 1978, Pařízek et al. 1980).

\section{Developmental aspects of biological effect of selenium}

While the beneficial effect of selenium during ontogeny is not known, the toxic actions are markedly dependent on the stage of the ontogenetic development. Prenatal administration of selenium has a teratogenic effect (Puzanová et al. 1976). In adult rats, one dose of sodium selenite $(20 \mu \mathrm{mol} / \mathrm{kg}$ body weight $)$ induces acute lethal syndrome. The animals die usually within the first two hours after the subcutaneous injection of selenite (Ošt'ádalová et al. 1978, 1979) with signs of cardiopulmonary failure (Fishbein 1977).

\section{Cataract of eye lens}

Suckling rats are entirely resistant to the lethal dose of selenite in comparison with adults. However, within one week after the same dose, the cataract of eye 
lens develops (Oštádalová et al. 1978); this original observation was later confirmed (Shearer et al. 1980, Bunce and Hess 1981, Palmquist et al. 1986). A single dose of sodium selenite administered on postnatal day 5 induced $98 \%$ of cataracts, $76 \%$ of cataracts when administrered on day 10, $48 \%$ was found when injected on day 15 and the incidence of cataracts decreased atmost to zero in animals that received selenite on day 20 . In older rats, cataracts of eye lens were never observed (Fig. 3A). It should be mentioned that high incidence of selenite-induced mortality occurred in 50-day-old rats and that the rats in the period between days 20 and 40 were markedly resistant to both cataractogenic and lethal effect of selenite. The increase of the selenite dose extended the lethal effect during the early stages of postnatal development, the period of sensitivity to cataractogenic action was, however, not changed (Fig. 3B) (Ošt’ádalová et al. 1979).
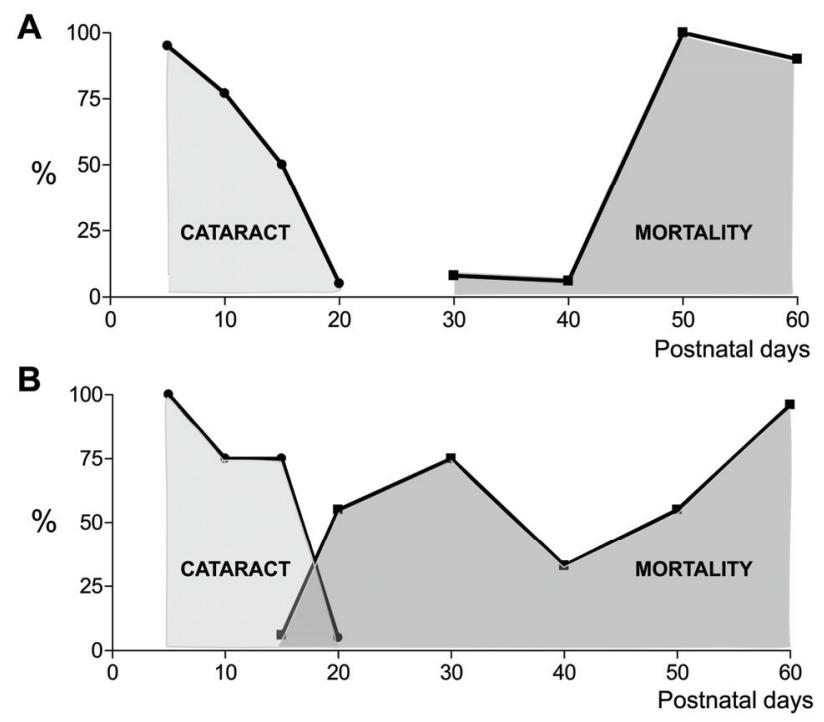

Fig. 3. Age dependence of cataractogenic and lethal effect induced by selenium. A single dose of sodium selenite: A) $20 \mu \mathrm{mol} / \mathrm{kg}$ b.w. s.c., B) $40 \mu \mathrm{mol} / \mathrm{kg}$ b.w. s.c. was administered on postnatal day $5,10,15,20,30,40,50,60$. Number of rats in the groups was more than 20. Values are expressed as percentage of injected animals at the age of 70 days. (Data from Ošt'ádalová et al. 1979.)

The cataractogenic effect is dependent on the chemical form of selenium (Ošt’ádalová and Babický 1980). While selenium in a higher oxidative form as selenate, D,L-selenomethionine, and D,L-selenocystine induces the cataract of the eye lens, other compounds, as dimethylselenide and trimethylselenonium ion, fail to induce it (Ošt’ádalová and Babický 1980). Critical period for cataractogenic action of selenite in rats correlates with the suckling period (Babický et al. 1970, Ošt'ádalová et al.
1978, 1979).

Our results indicate a strong dependence of selenium toxic effect on the ontogenetic development and suggest a different, developmental mechanism of detoxication or a different sensitivity to the adverse impact of selenium as an oxidant. There is a marked developmental difference in the retention and excretion of toxic doses of selenite. In suckling rats, almost 10 times higher concentration of selenium was observed in the blood, liver, kidney and heart up to day 7 after selenite administration. The highest concentration in the immature rats was in the liver while in the adults it was in the kidney (Table 1) (Ošt’ádalová et al. 1988). Surprisingly, during 2 hours after selenite administration, the suckling rats excrete selenium in the urine only; the adults excreted 5 times higher amount equally in urine and breath (Table 2) (Ošt’ádalová et al. 1982). The methylated metabolites were present in a several times higher proportion in adults as compared with sucklings (Table 3, Fig. 4) (Ošstádalová et al. 1982).

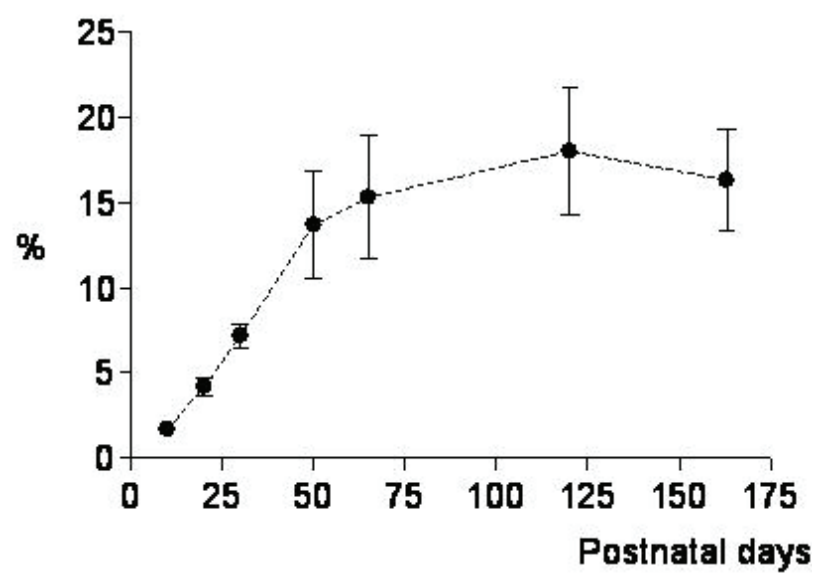

Fig. 4. Age dependence of $\left(\mathrm{CH}_{3}\right)_{3}{ }^{75} \mathrm{Se}^{+}$concentration in rat urine after administration of $\mathrm{Na}_{2}{ }^{75} \mathrm{SeO}_{3}$. Content of trimethylselenonium ion during $2 \mathrm{~h}$ after injection of $20 \mu \mathrm{mol} / \mathrm{kg}$ b. w. $\mathrm{Na}_{2}{ }^{75} \mathrm{SeO}_{3}$ s.c. expressed as a percentage of whole activity in urine. 6-8 rats per group, values are expressed as mean \pm S.E.M. (Data from Ošt'ádalová et al. 1982.)

\section{Possible mechanisms of the selenium-induced cataract}

There are numerous ontogenetic differences that might be resposible for the different response to selenium in sucklings and adults. The main difference is in the nutrition. Mother milk is the source of both nutrients and water for the pups. It is known that one of the initial phases of cataract formation is the permeation of water into the lens due to the disturbance of the permeability of lens epithelium membrane, resulting in lens opacity (Obenberger 1977, Martinez and de Iongh 2010). 
A

a. Total proteins

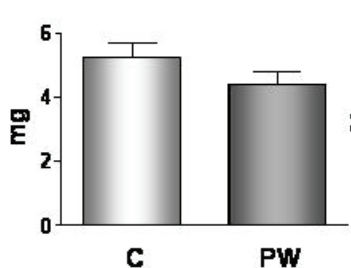

B

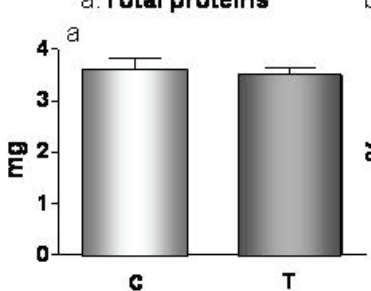

b. Water-insoluble proteins

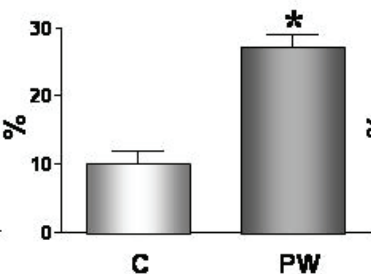

C

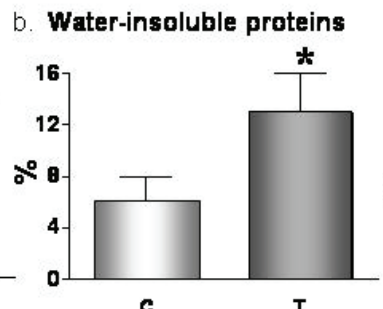

C. Incidence of cataracts

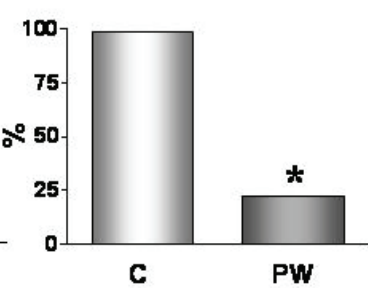

C. Incidence of cataracts insoluble proteins as \% of total proteins (b) were estimated on postnatal day 14 ( 8 rats per groups). The incidence of cataracts induced on day 14 by a single dose of $30 \mu \mathrm{mol} / \mathrm{kg} \mathrm{b.} \mathrm{w}$. $\mathrm{Na}_{2} \mathrm{SeO}_{3}$ in thyroxine pretreated youngs (c) was evaluated as a percentage on postnatal day 60 (10 rats per group). Means \pm S.E.M., $*$ p $<0.05$.

Table 1. ${ }^{75} \mathrm{Se}$-concentration in tissues and urine of young and adult rats.

\begin{tabular}{|c|c|c|c|c|c|c|}
\hline & \multirow[b]{2}{*}{ Day } & \multicolumn{5}{|c|}{$\%$ of administered dose } \\
\hline & & $\begin{array}{l}\text { Blood } \\
\% / g\end{array}$ & $\begin{array}{l}\text { Liver } \\
\% / g\end{array}$ & $\begin{array}{c}\text { Kidney } \\
\text { \%/g }\end{array}$ & $\begin{array}{l}\text { Heart } \\
\% / g\end{array}$ & $\begin{array}{l}\text { Urine } \\
\% / m l\end{array}$ \\
\hline \multirow{2}{*}{ Young } & 1 & $3.96 \pm 0.15$ & $11.85 \pm 0.96$ & $3.87 \pm 0.16$ & $1.27 \pm 0.06$ & $2.62 \pm 0.19$ \\
\hline & 7 & $1.54 \pm 0.09$ & $6.46 \pm 1.11$ & $2.00 \pm 0.10$ & $0.55 \pm 0.03$ & $0.31 \pm 0.06$ \\
\hline \multirow{2}{*}{ Adults } & 7 & $0.43 \pm 0.03$ & $0.51 \pm 0.04$ & $0.80 \pm 0.10$ & $0.09 \pm 0.02$ & $1.92 \pm 0.20$ \\
\hline & 7 & $0.11 \pm 0.003$ & $0.16 \pm 0.01$ & $0.34 \pm 0.03$ & $0.05 \pm 0.003$ & $0.03 \pm 0.01$ \\
\hline
\end{tabular}

Values found after s.c. injection of $30 \mu \mathrm{mol} / \mathrm{kg}$ b.w. $\mathrm{Na}_{2}{ }^{75} \mathrm{SeO}_{3}$ to young rats (14 days old) or $15 \mu \mathrm{mol} / \mathrm{kg} \mathrm{b} \mathrm{w}$. $\mathrm{Na}_{2}{ }^{75} \mathrm{SeO}{ }_{3}$ to adult rats (90 days old), 6-8 rats per group, values are expressed as means \pm S.E.M. (Adapted from Ošt’ádalová et al. 1988.)

Table 2. Ontogenic changes in ${ }^{75} \mathrm{Se}$ excretion.

\begin{tabular}{|c|c|c|c|c|}
\hline \multirow[b]{2}{*}{ Age, day } & \multicolumn{2}{|c|}{$\%$ of administered dose } & \multicolumn{2}{|c|}{$\%$ of total excretion } \\
\hline & 10 & 65 & 10 & 65 \\
\hline Expired air & $0.06 \pm 0.01$ & $5.52 \pm 0.77$ & 2.5 & 50.3 \\
\hline Urine & $2.33 \pm 0.27$ & $5.46 \pm 0.54$ & 97.5 & 49.7 \\
\hline Total & $2.39 \pm 0.27$ & $10.98 \pm 0.94$ & 100.0 & 100.0 \\
\hline
\end{tabular}

${ }^{75} \mathrm{Se}$ excretion during $2 \mathrm{~h}$ after the injection of $20 \mu \mathrm{mol} / \mathrm{kg}$ b.w. $\mathrm{Na}_{2}{ }^{75} \mathrm{SeO}_{3}$ S.c., $6-8$ rats per group. Values are expressed as means \pm S.E.M. (Adapted from Ošt'ádalová et al. 1982.)

The hydration of the pups after birth markedly differs in comparison with the older age. The newborns face the severe sudden stop of transplacental nutrition. It means that during the first several hours after birth the neonates overcome the hunger and the thirst. Their hydration is depressed and no selenium-induced cataract in these days was observed. During the following days, lactation as well as the hydration of sucklings is increasing. The next period of lower hydration starts at the end of the suckling period, i.e. on day 16. The amount of maternal milk is not adequate; the youngs start to consume solid food. Presumably the balance between 
Table 3. Selenium metabolites in urine in young and adult rats.

\begin{tabular}{lrr} 
Age (days) & 10 & \multicolumn{1}{c}{65} \\
$\begin{array}{l}\text { Metabolites in urine (\%) } \\
\text { 1. }{ }^{75} \mathrm{SeO}_{3}{ }^{2-}\end{array}$ & \\
2. $(\mathrm{GS}){ }_{2}{ }^{75} \mathrm{Se}$ & $54.5 \pm 5.8$ & $66.1 \pm 5.0$ \\
3. Start line & $15.1 \pm 1.6$ & $7.2 \pm 1.0$ \\
4. $\left(\mathrm{CH}_{3}\right){ }_{3}{ }^{75} \mathrm{Se}^{+}$ & $27.7 \pm 6.4$ & $8.5 \pm 1.5$ \\
Total & $1.8 \pm 0.3$ & $14.6 \pm 3.6$ \\
\end{tabular}

Selenium metabolites excretion during $2 \mathrm{~h}$ after injection of $20 \mu \mathrm{mol} / \mathrm{kg}$ b. w. $\mathrm{Na}_{2}{ }^{75} \mathrm{SeO}_{3}$ s.c., 6-8 rats per group. Values are expressed as means \pm S.E.M. (Adapted from Oštádalová et al. 1982.)

supplied calories and water in the mother milk is disturbed by the intake of other calories from the solid food. It seems that this is the reason why water intake follows the intake of solid food, since the immature rats have to keep the osmotic balance (Babický et al. 1970, 1972, 1973). It seems that by the end of the suckling period, the hydration decreases and sensitivity to cataractogenic effect of selenite disappears.

Premature weaning on day 14 after birth decreases significantly the hydration of youngs and coincides with a decreased incidence of selenium cataract (Fig. 5A) (Babický and Oštádalová 1982, Oštádalová and Babický 1984). It is possible to speculate that higher hydration, typical for neonates, at the time of the advanced milk intake, is probably the essential prerequisite for the cataract development.

To analyze this problem the rats with a disturbance of hydration were investigated. For this purpose the neonates of homozygotes of Brattleboro rats were used. These rats have a congenital defect in water metabolism, resulting from a complete lack of vasopressin synthesis in the hypothalamus, subsequently inducing diabetes insipidus. Their hydration is significantly lower (increased hematocrit, plasma osmolarity, Valtin and Schrier 1997). It has been observed that these rats do not develop selenium cataract at all (Table 4) (Babický et al. 1982).

It thus appears that water content is one of the factors important for the maintenance of eye lens transparence and it is regulated by an active transport of $\mathrm{Na}^{+}$and $\mathrm{K}^{+}$in the lens epithelium. The uptake of rubidium ${ }^{86} \mathrm{Rb}^{+}$- analogous to $\mathrm{K}^{+}$uptake - into rat eye lens in the experiments in vitro, differs substantially with age. A rapid drop in the uptake of ${ }^{86} \mathrm{Rb}$ was found in the lens during neonatal period, critical for the development of selenium cataract (Sládková et al. 1984). In the neonatal period, ${ }^{75} \mathrm{Se}$ uptake by lenses in vivo is almost
500 times higher and in vitro 5 times higher in comparison with the adult rats. It may reflect the agedependent differences in the structure and function of cellular and subcellular membranes (Babický et al. 1985).

Table 4. Incidence of selenium-induced cataract in rats Brattleboro strain.

\begin{tabular}{lcll}
\hline $\begin{array}{l}\text { Age (days) } \\
\text { Heterozygotes }\end{array}$ & 65 & & 65 \\
Male $(\mathrm{n}=10)$ & 90 & Momozygotes & \\
Female $(\mathrm{n}=12)$ & 92 & Female $(\mathrm{n}=10)$ & 0 \\
\hline
\end{tabular}

Incidence in 2 months old rats after injection of $30 \mu \mathrm{mol} / \mathrm{kg} \mathrm{b}$. w. $\mathrm{Na}_{2} \mathrm{SeO}_{3}$ s. c. on day 10 of postnatal life. (Data from Babický et al. 1982.)

The other important developmental change is the content of total proteins in the eye lens. This parameter increases during the entire suckling period. However, the fraction of water insoluble proteins markedly decreases after birth with a maximum on day 5 and increases again to postnatal day 20. The decay of this protein fraction corresponds with the period of sensitivity to the cataractogenic effect of selenite (Fig. 6A, B).

It is known that the treatment with exogenous thyroxine accelerates the maturation of young rats. The rats open their eyes earlier ( $10.5 \pm 0.5$ postnatal day) than the controls ( $14.2 \pm 0.2$ postnatal day), they terminate the intake of maternal milk 3-4 days earlier but they are not different from controls in the onset of solid food intake. The fraction of water-insoluble proteins in their eyes increases significantly in comparison with non-treated controls and the incidence of cataracts in thyroxine-treated youngs is significantly limited (Hrdličková et al. 1985). It seems that the protein composition in eye lenses plays a crucial role in the development of selenium cataract (Fig. 5B). 

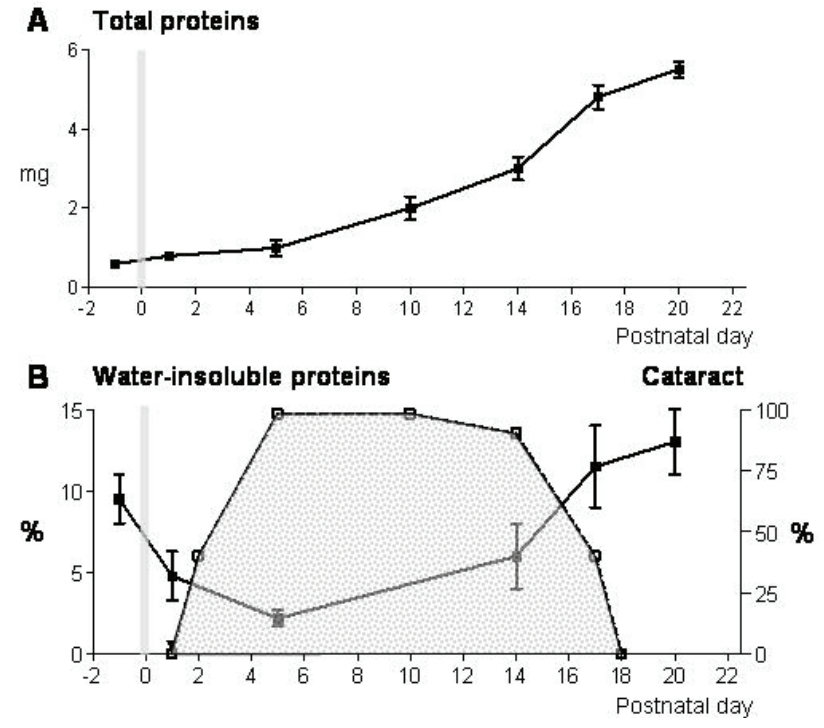

Fig. 6. Dependence of selenium-induced cataracts on the postnatal development of lenticular proteins. Estimation of total proteins in $\mathrm{mg}$ from day 1 to 20 (A), and fraction of waterinsoluble proteins expressed as \% of total proteins ( 8 rats per group, full square) in relation to incidence of cataracts (empty square) induced by a single dose of $30 \mu \mathrm{mol} / \mathrm{kg} \mathrm{b}$. w. $\mathrm{Na}_{2} \mathrm{SeO}_{3}$ on day $1,2,5,10,14,15,17$ and 18 expressed as a percentage (B), (7-9 rats per group).

It is interesting that the above mentioned mercury-selenium interaction in the relation to mortality may be demonstrated even in the relation to the development of eye lens cataract. In young rats, which are sensitive to the cataractogenic effect, mercury inhibits the development of selenium-induced cataract (Shearer et al. 1983). The protective effect of mercury is, however, not accompanied by the decrease of selenium compounds, because mercury increased ${ }^{75} \mathrm{Se}$ uptake into lenses in experiments in vitro (Kopoldová et al. 1985, Ošt’ádalová et al. 1989) as well as in vivo (Ošt'ádalová et al. 1985a,b). Similarly, selenium interacts in the eye lens with thallium: simultaneous administration of thallium together with cataractogenic dose of selenite protects the young rats against the development of selenium-induced cataract (Ošt’ádalová and Babický 1986, 1987). In this connection it is very interesting to mention that the rats in the developmental period between day 18 and 40, when no cataract was observed, was also resistant to the lethal effect of selenium. This question should be the topic of further experiments.

Selenium-induced cataract became an extremely rapid and convenient model of nuclear cataract, widely used for modelling of various mechanisms of cataract formation and for the screening potential of anti-cataract agents (Yilmaz et al. 2000, Zigler et al. 2007, Aydin et al. 2009, Doganay et al. 2009, Kyselová 2010).

\section{The role of selenium in cell signalling}

Selenium occurs in the periodic table between sulfur and tellurium; it is very similar to sulfur in a number of respects and forms the analogous compounds in a different oxidative level: elemental selenium (0), selenide $(-2)$, selenite $(+4)$ and selenate $(+6)$. The possibility to convert selenium into a different oxidative level is a very important property for transfer of oxygen radicals.

There are two major pathways for cell signalling: i) phosphorylation of proteins or ii) changes in the thiol status of proteins due to changes in the redox environment of the cell. „Redox state of the cell“" is defined as a balance between reactive oxygen species (ROS) production and their removal by antioxidant systems. ROS are derived from many sources; however, their main source is NADPH oxidase. Both oxidative and reductive stress can trigger redox cascades that bring about changes in the thiol status of the cell. Oxidative stress develops as an imbalance between the production of ROS and the antioxidant defense. However, it is no longer acceptable that ROS are always detrimental to the organism and that high levels of antioxidants must be beneficial due to their scavenging properties (Upham and Trosko 2009). Actually ROS are considered not only a by-product of metabolism but a critical regulator of multiple intracellular signaling cascades. More reactive radicals, such as superoxide and the hydroxyl radical, are unstable and they are unlikely to travel significant distances from the site of their synthesis. They are removed by antioxidant enzyme such as superoxide dismutase that reduces superoxide and hydroxyl radicals to $\mathrm{H}_{2} \mathrm{O}_{2}$. However, $\mathrm{H}_{2} \mathrm{O}_{2}$ has a very low molecular weight, not much different from that of water, and thus can readily traverse the channels and gap junctions and can consequently serve as ideal second messengers in a network of signalling pathways to maintain tissue homeostasis.

Oxidants at noncytotoxic doses can reversibly control the expression of genes. There are a number of genes and signal proteins reported to be sensitive to the redox state in the cell. A response of a cell to growth factors is a transient production of $\mathrm{H}_{2} \mathrm{O}_{2}$, as a product of NADPH oxidase. Besides gluthathione peroxidase, the cells posses the other antioxidant enzyme that reduces hydrogen peroxide such as catalase (it reduces $\mathrm{H}_{2} \mathrm{O}_{2}$ to $\mathrm{H}_{2} \mathrm{O}$ ). However, whereas glutathione peroxidase acts on relatively low levels of hydrogen peroxide, catalase acts 
to remove high concentrations or bursts of hydrogen peroxide formation (Meister 1982), and is present mainly in the peroxisomes. To protect against the ROS-induced damage, the GSSH/GSH ratio has a fundamental importance in the cardiomyocytes, because it markedly modulates the cellular redox state. The GSSH/GSH ratio is thus predominantly maintaned by two enzymes glutathione reductase and selenoenzyme glutathione peroxidase (Fig. 2). Glutathione peroxidase is the first well-defined (but not the only) enzyme containing selenium, which is able as the other selenoproteins to take part in electron transfer reactions (Stadtman 1974).

Changes in the cellular redox environment can alter the status of the cell. Schafer and Buettner (2001) and $\mathrm{Ng}$ et al. (2007) opened a new field of quantitative biology, a rationale of cellular mechanisms associated with cell growth, development, signalling and reduction or oxidative stress. They presented that the changes of the half-cell reduction potential $\left(\mathrm{E}_{\mathrm{hc}}\right)$ of the GSSH/GSH appear to correlate with the biological status of the cell: proliferation, differentiation and apoptosis corresponds to $\mathrm{E}_{\mathrm{hc}} \approx 240 \mathrm{mV}, \approx 200 \mathrm{mV}$, and $\approx 170 \mathrm{mV}$, respectively. The rate of removal of $\mathrm{H}_{2} \mathrm{O}_{2}$ was a direct function of GPx activity x GSH (effectivity GPx activity). The predicted cellular average GPx and $\mathrm{H}_{2} \mathrm{O}_{2}$ for their study are approximately GPx $\leq 1 \mu \mathrm{m}$ and $\mathrm{H}_{2} \mathrm{O}_{2} \approx 5 \mu \mathrm{m}$ based on available rate constants and an estimation of GSH. Thus GPx is an adaptive enzyme increasing in response to oxidative stress, ageing, physical activity, iron deficiency anaemia (Kok et al. 1987) and level of bioavailable selenium which defines its activity.

The example of significant changes connected with ROS production is the newborn heart. At birth the mammalian heart meets suddenly with an extremely high ROS concentration as a consequence of the dramatic changes of the living conditions during the delivery: barometric pressure increases more than 3 times (from 226 to $760 \mathrm{~mm} \mathrm{Hg}$ ), $\mathrm{PO}_{2}$ in the air increases more than 3 times (from 47 to $160 \mathrm{~mm} \mathrm{Hg}$ ) and arterial $\mathrm{O}_{2}$ saturation increases even more than 5 times (from 18 to $97 \%$ ). ROS attack the proteins and other molecules and produce autophagocytized material - lipofuscin like pigments (LFP) (Heintz 2004, Kuma et al. 2004, Gustafsson and Gottlieb 2009). The analysis of cardiac LFP concentration during the early postnatal period in the rat heart revealed marked oscillations: a high value on day 1 , a sharp decay on day 4 and an increase again on day 7 followed by a decrease to day 15 (Ošt'ádalová et al. 2010). These alterations are probably induced by the adaptation to the squall of ROS after the birth. LFP concentration in the immature heart (10-day-old) can be significantly influenced by selenium supplementation of the pregnant and lactating females. The developmental oscillations of LFP were significantly reduced and ROS production was thus counterbalanced in order to maintain the redox potential (Fig. 7). The maximum value of heart weight/body weight ratio, that is at control rats on day 4 (Ošt’ádal et al. 1967, Ošt’ádalová et al. 1993), was in selenium-supplemented neonates shifted on day 7 (Ošt’ádalová et al. 2010).

Redox-sensitive signalling pathways have a key cellular importance in maintaining the balance between processes such as growth, proliferation, differentiation, migration, apoptosis and death (Sauer et al. 2001, Schafer and Buettner 2001, Ushio-Fukai and Alexander 2004, Ushio-Fukai 2007, Upham and Trosko 2009). By means of oxidative and reduction properties, selenium participates in the keeping of ,redox homeostasis“, and it is able to reset the redox potential to the original state. Selenium has thus an essential role for the fundamental cellular functions. A typical example of the role of selenium in the redox-sensitive signalling is its possible role in the cardioprotective action.

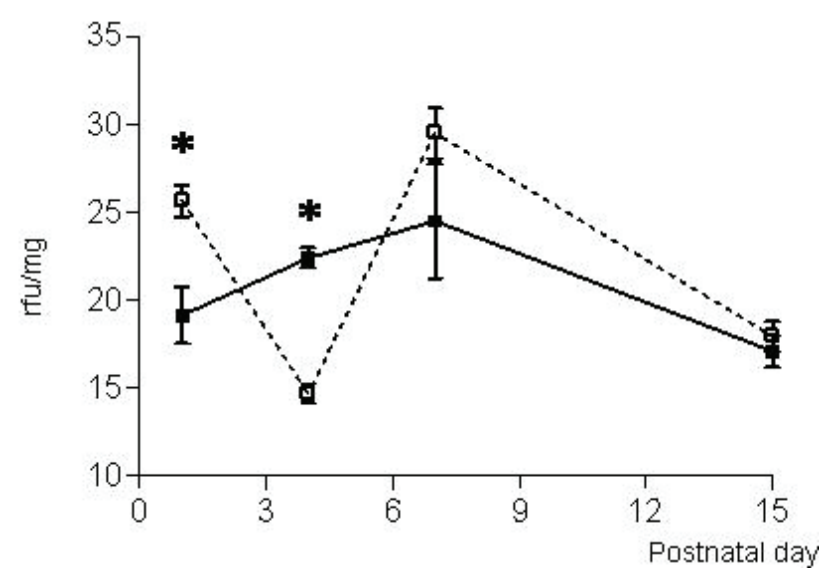

Fig. 7. Effect of long-time selenium supplementation on the development of myocardial LFP concentration (LFP fluorophore $350 / 450$, expressed as $\mathrm{rfu} / \mathrm{mg}$, full line, $n=8$ ). The rats were fed by mothers that were drinking $2 \mathrm{ppm}$ of $\mathrm{Na}_{2} \mathrm{SeO}_{3}$ in water starting from the conception, during the whole pregnancy up to day 10 after delivery. Controls (dotted line, $n=8$ ) were fed by control mothers. Means \pm S.E.M., ${ }^{*} p<0.05$. (Data from Ošt'ádalová et al. 2010.)

\section{Cardioprotective effect of selenium}

At present, cardiovascular diseases represent the most important health risk because they are responsible 
for more than $50 \%$ of the total mortality. The leading cause of morbidity and mortality is the ischemic heart disease (for review see Oštádal 2009). Ischemia/reperfusion injury is closely related to the development of ROS. It is, therefore, understandable that many investigators are interested in the analysis of the role of oxidative and antioxidative compounds. Selenium thus became the focus of clinical and experimental observations.

The results of clinical studies are very controversial. Some of them demonstrated a beneficial effect of selenium: lower plasma concentration of selenium was connected with higher concentrations of proinflammatory cytokines of TNF- $\alpha$ and IL-6 in patients, suffering from the acute myocardial infarction (Hassanzadeh et al. 2006). A relation of selenium and the degree of myocardial damage in ischemic heart disease was observed: dietary selenium supplementation may provide a method for increasing antioxidant protection, particularly in the individuals at risk for ischemic heart disease or in those, undergoing clinical procedures, involving transient periods of myocardial hypoxia (Venardos et al. 2007). C-reactive protein showed a significant positive correlation with the markers of cardiac damage (cTnT and cTnI) and a significant negative correlation with glutathione peroxidase. It suggests that the selenium level is related to the degree of myocardial damage and thus plays a role in the pathogenesis of ischemic heart disease (Altekin et al. 2005). The patients maintained for a long time on total parenteral nutrition, who are compromised from selenium deficiency, are recommended for a selenium supplementation (van Rij et al. 1981, Baker et al. 1983).

Other studies indicate no positive effect of selenium supplementation on the primary prevention of cardiovascular disease (Néve 1996, Stranges et al. 2005). Similarly, a randomized trial among the U.S. physicians (Salvini et al. 1995) showed no signs of protective effect of selenium and no reduced risk of myocardial infarction. The results of longitudinal studies are conflicting (Huttunen 1997) and the treatment of cardiovascular diseases with selenium still remains insufficiently documented. Rapid alterations in the serum level of selenium during the acute phase of myocardial infarction, as it was recently presented, indicates the relevance of time of selenium sampling and contributes to controversies of published results (Kutil et al. 2010). The inconsistency of the above results is not easy to explain. The dose and the chemical form of selenium, the interactions, previous history of patients as well as the time of sampling have to be taken into consideration. Further epidemiological studies and randomized clinical trials across populations with different selenium status should be conducted to determine the causal effect of selenium on cardiovascular disease and risk factors (Stranges et al. 2010).

The experiments demonstrated that selenium reduces myocardial arrhythmia score and infarct size (Tanguy et al. 1998, 2004, 2010), improves recovery of the heart after ischemia/reperfusion injury (Poltronieri et al. 1992, Pucheu et al. 1995, Dhalla et al. 2000, Venardos et al. 2004, Lymbury et al. 2006), limits post-infarction cardiac remodelling and inhibits nuclear translocation of NF- $\mathrm{BB}$ during myocardial infarction (Turan et al. 2005, Panicker et al. 2010).

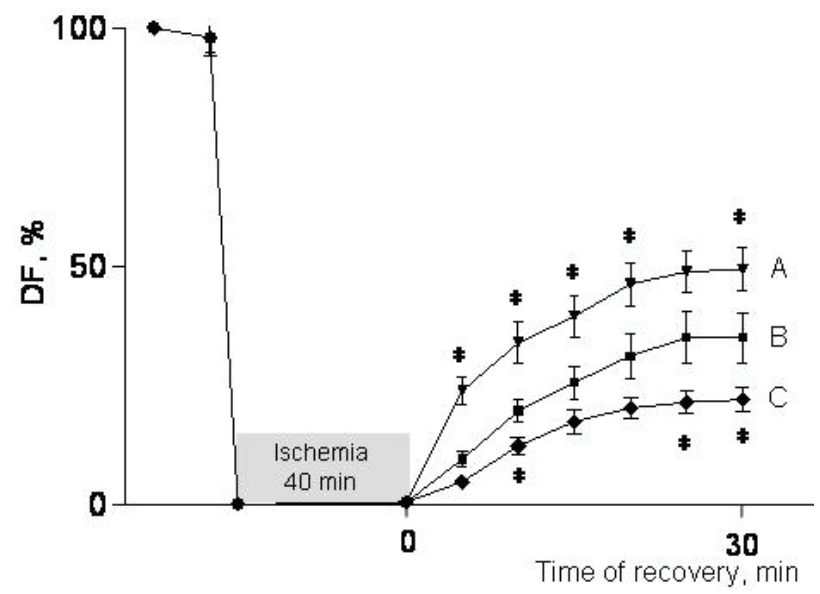

Fig. 8. Effect of addition of $\mathrm{Na}_{2} \mathrm{SeO}_{3}$ into Krebs-Henseleit solution (in a final concentration of $75 \mathrm{nmol.}^{-1}$ ) on the recovery of isolated heart contractility (measured as a developed force) after global ischemia (expressed as a percentage of baseline value) in 10 day-old rats; controls (B), preischemic perfusion with selenium (C) and postischemic perfusion with selenium (A). Means \pm S.E.M., $* p<0.05$. (Data from Ošt'ádalová et al. 2007.)

In all these experiments exclusively adult rats were used while the data concerning the immature heart were lacking. The aim of our study was, therefore, to find out whether selenium can protect also the immature heart against ischemia (Ošt'ádalová et al. 2007). We have observed that the addition of selenium to the perfusion solution during reperfusion significantly increased the recovery of the isolated neonatal rat heart. However, addition of selenium into perfusion solution before global ischemia had an adverse effect: the recovery after ischemia-reperfusion injury was markedly decreased (Fig. 8). These experiments suggest that the moderate 
concentration of ROS developing during perfusion before ischemia is probably necessary, for their signalling role; the addition of selenium as antioxidant limits their function (Suzuki et al. 1997, Sauer et al. 2001). On the other hand, the production of ROS during reperfusion is high (Zweier et al. 1988) and the addition of antioxidative substance is thus beneficial.

A similar protective effect was also observed after long-lasting treatment of the immature hearts. Adult female rats were supplemented with selenite during pregnancy until day 10 post partum. Their fetuses were taking selenium through placenta till birth; after birth the sucklings were supplemented with selenium through mother milk. The isolated, perfused hearts of these selenium-supplemented 10-day-old sucklings were significantly more resistent against global ischemiareperfusion injury in comparison with controls. In addition, serum concentration of NO in seleniumsupplemented sucklings decreased, suggesting better antioxidative equipment (Ošt’ádalová et al. 2007).
Moreover, selenium supplementation increased significantly the sensitivity to the inotropic effect of isoproterenol. This is in a good agreement with recently published data demonstrating, that production of ROS in adult mouse cardiomyocytes contributes to the $\beta$-adrenergic stimulation (Sayar et al. 2000, Gomez et al. 2003, Andersson et al. 2011).

The results reviewed in this paper showed both beneficial and toxic effects of the trace element selenium. However, the questions of optimal levels of selenium in the diet, possible toxicity and interactions should be the topic of further studies.

\section{Conflict of Interest}

There is no conflict of interest.

\section{Acknowledgements}

This study was supported by grant of MSMT 1M0510, and grant AV0Z 50110509. The author thanks Mrs. M. Pešková for technical assistance.

\section{References}

AGARWAL R, BEHARI JR: Role of selenium in mercury intoxication in mice. Ind Health 45: 388-395, 2007.

ALLEN JC, MILLER WJ: Transfer of selenium from blood to milk in goats and noninterference of copper with selenium metabolism. J Dairy Sci 64: 814-821, 1981.

ALTEKIN E, COKER C, SISMAN AR, ONVURAL B, KURALAY F, KIRIMLI O: The relationship between trace elements and cardiac markers in acute coronary syndromes. J Trace Elem Med Biol 18: 235-242, 2005.

ANDERSSON DC, FAUCONNIER J, YAMADA T, LACAMPAGNE A, ZHANG SJ, KATZ A, WESTERBLAD H: Mitochondrial production of reactive oxygen species contributes to the $\beta$-adrenergic stimulation of mouse cardiomyocytes. J Physiol 589: 1791-1801, 2011.

AYDIN B, YILMAZ FM, ERDURMUS M, KARADAG R, KESKIN U, DURMUS M, YIGITOGLU R: Prevention of selenite-induced cataractogenesis by N-acetylcysteine in rats. Curr Eye Res 34: 196-201, 2009.

BABICKÝ A, OŠŤÁDALOVÁ I: Protective effect of premature weaning against the appearance of selenium induced cataract in young rats. IRCS Medical Science 10: 464, 1982.

BABICKÝ A, OŠŤÁDALOVÁ I, PAŘÍZEK J, KOLÁŘ J, BÍBR B: Use of radioisotope techniques for determining the weaning period in experimental animals. Physiol Bohemoslov 19: 457-467, 1970.

BABICKÝ A, PAVLÍK L, PǍ̌ÍZEK J, OŠŤÁDALOVÁ I, KOLÁŘ J: Determination of the onset of spontaneous water intake in infant rats. Physiol Bohemoslov 21: 467-571, 1972.

BABICKÝ A, PAŘIZZK J, OŠŤÁDALOVÁ I, KOLÁŘ J: Initial solid food intake and growth of young rats of different sizes. Physiol Bohemoslov 22: 557-566, 1973.

BABICKÝ A, OŠŤÁDALOVÁ I, ZICHA J, KŘEČEK J: Peculiar response of Brattleboro rats to selenite. Experientia 38: $839,1982$.

BABICKÝ A, RYCHTER Z, KOPOLDOVÁ J, OŠŤÁDALOVÁ I: Age dependence of selenite uptake in rat eye lenses. Exp Eye Res 40: 101-103, 1985.

BARCELOUX DG: Selenium. J Toxicol Clin Toxicol 37: 145-172, 1999.

BIANCO AC, SALVATORE D, GEREBEN B, BERRY MJ, LARSEN PR: Biochemistry, cellular and mollecular biology, and physiological roles of the iodothyronine selenodeiodinases. Endocr Rev 23: 38-89, 2002. 
BERRY MJ, BANU L, LARSEN PR: Type I iodothyronine deiodinase is a selenocysteine-containing enzyme. Nature (Lond) 349: 438-440, 1991.

BUETTNER GR, JURKIEWICZ BA: Catalytic metals, ascorbate and free radicals: combinations to avoid. Radiat Res 145: 532-541, 1996.

BUNCE GE, HESS JL: Biochemical changes associated with selenite-induced cataract in the rat. Exp Eye Res 33: 505$514,1981$.

BURK RF: Selenium, an antioxidant nutrient. Nutr Clin Care 5: 75-79, 2002.

BURK RF, HILL KE, MOTLEY AK: Selenoprotein metabolism and function: evidence for more than one function for selenoprotein P. J Nutr 133: 1517S-1520S, 2003.

CERMELLi C, VINCETI M, SCALTRITI E, BAZZANI E, BERETTI F, VIVOLI G, PORTOLANI M: Selenite inhibition of Coxakie virus B5 replication: implications on the etiology of Keshan disease. J Trace Elem Med Biol 16: 41-46, 2002.

CHAMBERS I, FRAMPTON J, GOLDFARB P, AFFARA N, MCBAIN W, HARRISON PR: The structure of the mouse glutathione peroxidase gene: the selenocysteine in the active site is encoded by the 'termination' codon, TGA. EMBO J 5: 1221-1227, 1986.

CHU FF, DOROSHOW JH, ESWORTHY RS: Expression, characterization, and tissue distributions of a new cellular selenium-dependent glutathione peroxidase, GSHPX-GI. J Biol Chem 268: 2571-2576, 1993.

DHALLA NS, ELMOSELHI AB, HATA T, MAKINO N: Status of myocardial antioxidants in ischemia-reperfusion injury. Cardiovasc Res 47: 445-456, 2000.

DIPLOCK AT: Indexes of selenium status in human populations. Am J Clin Nutr Suppl 57: S256-S268, 1993.

DOGANAY S, BORAZAN M, CIGREMIS Y: The effect of resveratrol in experimental cataract model formed by sodium selenite. Curr Eye Res 31: 147-153, 2006.

DUARTE TL, LUNEC J: Review: When is an antioxidant not an antioxidant? A review of novel actions and reactions of vitamin C. Free Radic Res 39: 671-686, 2005.

ENJALBERT F, LEBRETON P, SALAT O, SCHELCHER F: Effect of pre- or postpartum selenium supplementation on selenium status in beef cows and theis calves. J Anim Sci 77: 223-229, 1999.

FISHBEIN L: Toxicology of selenium and tellurium. In: Toxicology of Trace Elements. RA GOYER, MA MEHLMAN (eds), John Wiley, New York, 1977, pp 191-240.

FRANKE KW, POTTER VR: The ability of rats to discriminate between diets of varying degrees of toxicity. Science 83: 330-332, 1936.

FUYU Y: Keshan disease and mitochondrial cardiomyopathy. Sci China C Life Sci 49: 513-518, 2006.

GASIEWICZ TA, SMITH JC: Properties of the cadmium and selenium complex formed in rat plasma in vivo and in vitro. Chem Biol Interact 23: 171-183, 1978.

GOMEZ RM, LEVANDER OA, STERIN-BORDA L: Reduced inotropic heart response in selenium-deficient mice relates with inducible nitric oxid synthase. Am J Physiol Heart Circ Physiol 284: H442-H448, 2003.

GUSTAFSSON AB, GOTTLIEB RA: Autophagy in ischemic heart disease. Circ Res 104: 150-158, 2009.

HASSANZADEH M, FARIDHOSSEINI R, MAHINI M, FARIDHOSSEINI F, RANIBAR A: Serum levels of TNF-, IL-6, and selenium in patiens with acute and chronic coronary artery disease. Iran J Immunol 3: 142-145, 2006.

HEINTZ N: Developmental biology: Survival by self-digestion. Nature 432: 963-967, 2004.

HRDLIČKOVÁ R, BABICKÝ A, OŠŤÁDALOVÁ I, NOVÁKOVÁ V: Some effects of thyroxine on the development of young rats. Physiol Bohemoslov 34: 427, 1985.

HUTTUNEN JK: Selenium and cardiovascular diseases - an update. Biomed Environ Sci 10: 220-226, 1997.

KALOUSKOVÁ J, PAVLÍK L: Protection against selenite toxicity by previous administration of selenium. Physiol Bohemoslov 31: 315-321, 1982.

KARIMPOUR I, CUTLER M, SHIH D, SMITH J, KLEENE KC: Sequence of the gene encoding the mitochondrial capsule selenoprotein of mouse sperm: identification of three in-phase TGA selenocysteine codons. DNA Cell Biol 11: 693-699, 1992.

KÖHRLE E: Thyroid hormone deiodinases - a selenoenzyme family acting as gate keepers to thyroid hormone action. Acta Med Austrica 23: 17-30, 1996. 
KOK FJ, DEBRUIJN AM, HOFMAN A, VALKENBURG HA: Selenium status and chronic disease mortality: Dutch epidemiological findings. Int J Epidemiol 16: 329-332, 1987.

KOPOLDOVÁ J, OŠŤÁDALOVÁ I, BABICKÝ A: Effect of mercury on the ${ }^{75}$ Se uptake and distribution in lenses of young rats. Physiol Bohemoslov 34: 433, 1985.

KUMA A, HATANO M, MATSUI M, YAMAMOTO A, NAKAYA H, YOSHIMORI T, OHSUMI Y, TOKUHISA H, MIZUSHIMA N: The role of autophagy during the early neonatal starvation period. Nature 432: 1032-1036, 2004.

KUTIL B, OŠŤÁDAL P, VEJVODA J, KUKAČKA J, ČEPOVÁ J, ALAN D, KRÜGER A, VONDRÁKOVÁ D: Alterations in serum selenium levels and their relation to troponin I in acute myocardial infarction. Mol Cell Biochem 345: 23-27, 2010.

KYSELOVÁ Z: Different experimental approach in modelling cataractogenesis. Interdisc Toxicol 3: 3-14, 2010.

LEVANDER OA, DELOACH DP, MORRIS VC, MOSER PB: Platelet glutathione peroxidase activity as an index of selenium status in rats. $J$ Nutr 113: 55-63, 1983.

LYMBURY R, VENARDOS K, PERKINS AV: Effect of sodium selenite-enriched reperfusion solutions on rat cardiac ischemia reperfusion injury. Biol Trace Elem Res 114: 197-206, 2006.

MARTINEZ G, DE IONGH RU: The lens epithelium in ocular health and disease. Intern J Biochem Cell Biol 42: $1945-$ 1963, 2010.

MEISTER A: Metabolism and function of glutathione: an overview. Biochem Soc Trans 10: 78-79, 1982.

MERTZ W: Metabolism and metabolic effects of trace elements. In: Trace Elements in Nutrition of Children. RK CHANDRA (ed), Nestlé Nutrition, Vevey/Raven press, New York, 1985, pp 107-119.

MORENO-REYES R, SUETENS C, MATHIEU F, BEGAUX F, ZHU D, RIVERA MT, BOELAERT M, NÉVA J, PERLMUTTER N, VANDERPAS J: Kashin-Beck osteoarthropathy in rural Tibet in relation to selenium and iodine status. $N$ Engl J Med 339: 1112-1120, 1998.

MOXON AL: The effect of arsenic on the toxicity on the seleniferous grains. Science 88: 81, 1938.

NÉVE J: Selenium as a risk factor for cardiovascular diseases. J Cardiovasc Risk 3: 42-47, 1996.

NG CF, SCHAFER FQ, BUETTNER CR, RODGERS VGJ: The rate of cellular hydrogene peroxide removal shows dependency on GSH: mathematical insight into in vivo $\mathrm{H}_{2} \mathrm{O}_{2}$ and GPx concentration. Free Rad Res 41: 12011211, 2007.

OBENBERGER J: Current knowledge on the ethiopathogenesis of cataracts (in Czech). Cesk Oftalmol 33: 291-296, 1977.

OŠŤÁDAL B: The past, the present and the future of experimental research on myocardial ischemia and protection. Pharmacol Rep 61: 3-12, 2009.

OŠŤÁDAL B, WACHTLOVÁ M, BÍLÝ J, RAKUŠAN K, POUPA O: Weight of the heart before and after birth. Physiol Bohemoslov 16: 111-115, 1967.

OŠŤÁDALOVÁ I, BABICKÝ A: Toxic effect of various selenium compounds on rat in the early postnatal period. Arch Toxicol 45: 207-211, 1980.

OŠŤÁDALOVÁ I, BABICKÝ A: Nutritional dependence of the incidence of selenite-induced cataracts in rats. Physiol Bohemoslov 33: 507-510, 1984.

OŠŤÁDALOVÁ I, BABICKÝ A: Selenium-thallium interaction in young rats. Physiol Bohemoslov 35: 553-554, 1986.

OŠŤÁDALOVÁ I, BABICKÝ A: Protective effect of thallium against the formation of selenium cataract in rats. Biol Trace Elem Res 14: 101-103, 1987.

OŠŤÁDALOVÁ I, BABICKÝ A, OBENBERGER J: Cataract induced by administration of a single dose of sodium selenite to suckling rats. Experientia 34: 222, 1978.

OŠŤÁDALOVÁ I, BABICKÝ A, OBENBERGER J: Cataractogenic and lethal effect of selenite in rats during postnatal ontogenesis. Physiol Bohemoslov 28: 393-397, 1979.

OŠŤÁDALOVÁ I, BABICKÝ A, KOPOLDOVÁ J: Ontogenic changes in selenite metabolism in rats. Arch Toxicol 49: 247-252, 1982.

OŠŤÁDALOVÁ I, BABICKÝ A, RYCHTER Z: Protective effect of mercury on the selenite-induced cataract. Physiol Bohemoslov 34: 449, 1985a. 
OŠŤÁDALOVÁ I, BABICKÝ A, RYCHTER Z: Analysis of the protective effect of sublimate on selenite-induced cataract (in Czech). Plzen Lék Sborn 49: 253-255, 1985b.

OŠŤÁDALOVÁ I, BABICKÝ A, KOPOLDOVÁ J: Selenium metabolism in rats after administration of toxic doses of selenite. Physiol Bohemoslov 37: 159-164, 1988.

OŠŤÁDALOVÁ I, BABICKÝ A, KOPOLDOVÁ J, ZIMOVÁ M: Effect of mercury on selenium binding to rat lens proteins in vitro. Physiol Bohemoslov 38: 427-432, 1989.

OŠŤÁDALOVÁ I, KOLÁŘ F, OŠŤÁDAL B, ROHLÍČEK V, ROHLÍČEK J, PROCHÁZKA J: Early postnatal development of contractile performance and responsiveness to $\mathrm{Ca}^{2+}$, verapamil and ryanodine in the isolated rat heart. J Mol Cell Cardiol 25: 733-740, 1993.

OŠŤÁDALOVÁ I, VOBECKÝ M, CHVOJKOVÁ Z, MIKOVÁ D, HAMPL V, WILHELM J, OŠŤÁDAL B: Selenium protects the immature rat heart against ischemia/reperfusion injury. J Mol Cell Biochem 300: 259-267, 2007.

OŠŤÁDALOVÁ I, CHARVATOVÁ Z, WILHELM J: Lipofuscin-like pigments in the rat heart during early postnatal development: effect of selenium supplementation. Physiol Res 59: 881-886, 2010.

PALMQUIST BM, FAGERHOLM P, LINDAU I: Selenium-induced cataract - a correlation of dry mass content and light scattering. Exp Eye Res 42: 35-42, 1986.

PANICKER S, SWATHY SS, JOHN F, MADAMBATH I: Impact of selenium on NFKB translocation in isoproterenolinduced myocardial infarction in rats. Biol Trace Elem Res 138: 202-211, 2010.

PAŘÍZEK J: Physiology of toxic elements. In: Physiological and Biochemical Aspects of 37 Heavy Elements in Our Environment. JPW HOUTMAN, CJA VAN DEN HAMER (eds), Delft University Press, Delft, 1975, pp 37-48.

PAŘÍZEK J: Interrelationship among trace elements. In: Effects and Dose-Response Relationships of Toxic Metals. GF NORDBERG (ed), Elsevier Scientific Publishing Company, Amsterdam, Oxford, New York, 1976, pp 498507.

PAŘÍZEK J: Interactions between selenium compounds and those of mercury or cadmium Environ Health Persp 25: 53-55, 1978.

PAŘÍZEK J, OŠŤÁDALOVÁ I: The protective effect of small amounts of selenite in sublimate intoxication. Experientia 23: 142-145, 1967.

PAŘÍZEK J, BABICKÝ A, OŠŤÁDALOVÁ I, KALOUSKOVÁ J, PAVLÍK L: The effect of selenium compounds on the cross-placental passage of ${ }^{203} \mathrm{Hg}$. In: Radiation Biology of the Fetal and Juvenile Mammal. MR SIKOV, DD MAHLUM (eds), U.S. Atomic Energy Commission, 1969a, pp 137-143.

PAŘÍZEK J, BENEŠ I, OŠŤÁDALOVÁ I, BABICKÝ A, BENEŠ J, PIŤHA J: The effect of selenium on the toxicity and metabolism of cadmium and some other metals. In: Mineral Metabolism in Paediatrics. D BARLTROP, WL BURLAND (eds), Blackwell scientific publications, Oxford and Edinburgh, 1969b, pp 117-134.

PAŘÍZEK J, OŠŤÁDALOVÁ I, KALOUSKOVÁ J, BABICKÝ A, BENEŠ J: The detoxifying effects of selenium interrelations between compounds of selenium and certain metals. In: Newer Trace Elements in Nutrition. W MERTZ, WE CORNATZER (eds), M. Dekker, New York 1971a, pp 85-122.

PAŘÍZEK J, OŠŤÁDALOVÁ I, KALOUSKOVÁ J, BABICKÝ A, PAVLÍK L, BÍBR B: Effect of mercuric compounds on the maternal transmission of selenium in the pregnant and lactating rat. $J$ Reprod Fert 25: 157$170,1971 b$.

PAŘÍZEK J, KALOUSKOVÁ J, BENEŠ J, PAVLÍK L: Interactions of selenium-mercury and selenium-selenium compounds. Ann NY Acad Sci 355: 347-360, 1980.

PARK A-M, SUZUKI YJ: Effects if intermittent hypoxia on oxidative stress-induced myocardial damage in mice. J Appl Physiol 102: 1806-1814, 2007.

POLTRONIERI R, CEVESE A, SBARBATI A: Protective effect of selenium in cardiac ischemia and reperfusion. Cardioscience 3: 155-160, 1992.

PUCHEU S, COUDRAY C, TRESALLET N, FAVIER A, DE LEIRIS J: Effect of dietary antioxidant trace element supply on cardiac tolerance to ischemia-reperfusion in the art. J Mol Cell Cardiol 27: 2303-2314, 1995.

PUZANOVA L, DOSKOCIL M, DOUBKOVA A: Embryonic and teratogenic action of selenium on chick embryos (in Czech). Sbornik lékařský 76: 269-275, 1976. 
ROBINSON MF, THOMPSON CD: Selenium levels in human vs. environmental sources. In: Selenium in Biology and Medicine. JE SPALLHOLZ, JL MARTIN, HE GANTHER (eds), Avi publishing company, Inc., Westport, Connecticut, 1981, pp 283-302.

ROTRUCK JT, HOEKSTRA WG, POPE AL: Relationship of selenium to GSH peroxidase. Fed Proc 31: 691-696, 1972.

SALVINI S, HENNEKENS CH, MORRIS JS, WILLETT WC, STAMPFER MJ: Plasma levels of the antioxidant selenium and risk of myocardial infarction among U.S. physicians. Am J Cardiol 76: 1218-1221, 1995.

SAUER H, WARTENBERG M, HESCHELER J: Reactive oxygen species as intracellular messengers during cell growth and differentiation. Cell Physiol Biochem 11: 173-178, 2001.

SAYAR K, UGUR M, GÜRDAL H, ONARAN O, HOTOMAROGLU O, TURAN B: Dietary selenium and vitamin E intakes alter $\beta$-adrenergic response of L-type Ca-current and $\beta$-adrenoreceptor-adenylate cyclase coupling in rat heart. J Nutr 130: 733-740, 2000.

SCHAFER FQ, BUETTNER CR: Redox environment of the cell as viewed through the redox state of the glutathione disulfide/glutathione couple. Free Rad Biol Med 30: 1191-1212, 2001.

SCHELENZ R: Dietary recommendation for trace element intake. In: Trace Element - Analytical Chemistry in Medicine and Biology, Vol 4. P BRÄTER, P SCHRAMEL (eds), Walter de Gruyter \& Co, Berlin NewYork, 1987, pp 79-105.

SCHOMBURG L, RIESE C, MICHAELIS M, GRIEBERT E, KLEIN MO, SAPIN R, SCHWEIZER U, KÖHRLE E: Synthesis and metabolism of thyroid hormones is preferentially maintained in selenium-deficient transgenic mice. Endocrinology 147: 1306-1313, 2005.

SCHWARZ K: Essentiality and metabolic functions of selenium. Med Clin N Am 60: 745-758, 1976.

SCHWARZ K, FOLTZ CM: Selenium as an integral part of factor 3 against dietary necrotic liver degeneration. $J \mathrm{Am}$ Chem Soc 79: 3292-3299, 1957.

SHEARER TR, ANDERSON RS, BRITTON JL: Influence of selenite and fourteen trace elements on cataractogenesis in the rat. Invest Ophthalmol Vis Sci 24: 417-423, 1983.

SHEARER TR, MCCORMACK DW, DESART DJ, BRITTON JL, LOPEZ MT: Histological evaluation of selenium induced cataract. Exp Eye Res 3: 327-333, 1980.

SKERFVING S: Interaction between selenium and methylmercury. Environ Health Perspect 25: 57-65, 1978.

SLÁDKOVÁ J, OŠŤÁDALOVÁ I, MICHL J, BABICKÝ A, OBENBERGER J: Uptake of ${ }^{86} \mathrm{Rb}$ by the rat lens during ontogeny. Physiol bohemoslov 33: 282, 1984.

STADTMAN TC: Selenium biochemistry. Science 183: 915-922, 1974.

STADTMAN TC: Biological function of selenium. Trends in Biochem Sci August: 203-206, 1980.

STEINNES E: Soils and geomedicine. Environ Geochem Health 31: 523-535, 2009.

STRANGES S, MARSHALL JR, TREVISAN M, NATARAJAN R, DONAHUE RP, COMBS GF, FARINARO E, CLARK LC, REID ME: Effects of selenium supplementation on vascular disease incidence and mortality: secondary analyses in a randomized clinical trials. Am J Epidemiol 163: 694-699, 2005.

STRANGES S, NAVAS-ACIEN A, RAYMAN MP, GUALLAR E: Selenium status and cardiometabolic health: state of the evidence. Nutr Metab Cardiovasc Dis 20: 754-760, 2010.

SU L, WANG M, YIN ST, WANG HL, CHEN L, SUN LG, RUAN DY: The interaction of selenium and mercury in the accumulations and oxidative stress of rat tissues. Ecotoxicol Environ Saf 70: 483-489, 2008.

SUZUKI YJ, FORMAN HJ, SEVANIAN A: Oxidants as stimulators of signal transduction. Free Radic Biol Med 22: 269-285, 1997.

TAKAHASHI K, COHEN HJ: Selenium-dependent glutathione peroxidase protein and activity: immunological investigations on cellular and plasma enzymes. Blood 68: 640-645, 1986.

TANGUY S, BOUCHER F, BESSE S, DUCROS V, FAVIER A, DE LEIRIS J: Trace elements and cardioprotection: increasing endogenous glutathione peroxidase activity by oral selenium supplementation in rats limits reperfusion-induced arrhythmias. J Trace Elem Med Biol 12: 28-38, 1998.

TANGUY S, MOREL S, BERTHONNECHE C, TOUFEKTSIAN MC, DE LORGERIL M, DUCROS V, TOSAKI A, DE LEIRIS J, BOUCHER F: Preischemic selenium status as a major determinant of myocardial infarct size in vivo in rats. Antioxid Redox Signal 6: 792-796, 2004. 
TANGUY S, RAKOVAO A, JOUAN MG, GHEZZI C, DE LEIRIS J, BOUCHER F: Dietary selenium intake influences $\mathrm{Cx} 43$ dephosphorylation, TNF- $\alpha$ expression and cardiac remodeling after reperfused infarction. Mol Nutr Food Res 55: 522-529, 2010.

THANNICKAL VJ, FANBURG BL: Reactive species in cell signaling. Am J Physiol Lung Cell Mol Physiol 279: L1005-L1028, 2000.

TURAN B, SAINI HK, ZHANG M, PRAJAPATI D, ELIMBAN V, DHALLA NS: Selenium improves cardiac function by attenuating the activation of NF-kappaB due to ischemia-reperfusion injury. Antioxid Redox Signal 7: 1388-1397, 2005.

UPHAM BL, TROSKO JE: Oxidative-dependent integration of signal transduction with intercellular gap junctional communication in the control of gene expression. Antioxid Redox Signal 11: 1-11, 2009.

URSINI F, MAIORINO M, GREGOLIN C: The selenoenzyme phospholipid hydroperoxide glutathione peroxidase. Biochim Biophys Acta 839: 62-70, 1985.

USHIO-FUKAI M: VEGF signaling through NADPH oxidase-derived ROS. Antioxid Redox Signal 9: 731- 739, 2007.

USHIO-FUKAI M, ALEXANDER RW: Reactive oxygen species as mediators of angiogenesis signalling: role of NAD(P)H oxidase. Mol Cell Biochem 264: 85-97, 2004.

VALTIN H, SCHRIER RW: Familiar hypothalamic diabetes insipidus in rats (Brattleboro strain). J Am Soc Nephrol 8: 1333-1341, 1997.

VAN RIJ AM, MCKENZIE JM, THOMSON CD, ROBINSON MF: Selenium supplementation in total parenteral nutrition. J Parent Enteral Nutr 5: 120-124, 1981.

VENARDOS K, HARRISON G, HEADRICK J, PERKINS A: Selenium supplementation and ischemia-reperfusion injury in rats. Redox Rep 9: 317-320, 2004.

VENARDOS KM, PERKINS A, HEADRICK J, KAYE DM: Myocardial ischemia-reperfusion injury, antioxydant enzyme system, and selenium: a review. Curr Med Chem 14: 1539-1549, 2007.

VENDELAND SC, BEILSTEIN MA, YEH J-Y, REAM W, WHANGER PD: Rat skeletal muscle selenoprotein W: cDNA clone and mRNA modulation by dietary selenium. Proc Natl Acad Sci USA 92: 8749-8756, 1995.

WANG Y-Z, JIA X-A, ZHAO J-Y, XU GL: Effects of selenium deficiency on Ca transport function of sarcoplasmic reticulum and lipid peroxidation in rat myocardium. Biol Trace Element Res 36: 159-166, 1993.

XIA Y, HILL KE, BYRNE DW, XU J, BURK RF: Effectiveness of selenium supplements in a low-selenium area of China. Am J Clin Nutr 81: 829-834, 2005.

YANG GQ: Keshan disease: an endemic selenium-related deficiency disease. In: Trace Element in Nutrition of Children. RA CHANDRA (ed), Nestlé Nutrition, Vevey/Raven Press, New York, 1985, pp 71-85.

YANG J-G, MORRISON-PLUMMER J, BURK RF: Purification and quantitation of a rat plasma selenoprotein distinct from glutathione peroxidase using monoclonal antibodies. J Biol Chem 262: 13372-13375, 1987.

YILMAZ G, TURAN B, CELEBI N, YILMAZ N, DEMIREL YILMAZ E: Prevention of selenite-induced opacification and biochemical changes in the rat pup lens through amiloride pretreatment. Curr Eye Res 20: 454-461, 2000.

ZIGLER JS JR, QIN C, KAMIYA T, KRISHNA MC, CHENG Q, TUMMINIA S, RUSSELL P: Tempol-H inhibits opacification of lenses in organ culture. Free Radic Biochem Med 35: 1194-1202, 2003.

ZWEIER JL, FLAHERTY JT, WEISFELDT ML: Measurement of free radical generation in the post-ischemic heart. In: Oxy-Radicals in Molecular biology and Pathology. Alan R Liss, Inc, 1988, pp 365-383. 